\title{
The problem of aspartimide formation during protein chemical synthesis using SEA-mediated ligation
}

Jennifer Bouchenna, Magalie Sénéchal, Hervé Drobecq, Jérôme Vicogne \& Oleg Melnyk

CNRS, Pasteur Institute of Lille, University of Lille, UMR CNRS 8204, Lille, France. Correspondence should be addressed to O.M. (oleg.melnyk@ibl.cnrs.fr).

\section{Summary}

Aspartimide formation often complicates the solid phase synthesis of peptides. Much less discussed is the potential occurrence of this side-reaction during the coupling of peptide segments using chemoselective peptide bond forming reactions such as the native chemical ligation and extended methods. Here we describe how to manage this problem using bis(2-sulfenylethyl)amido (SEA)mediated ligation.

Key words: Aspartimide, bis(2-sulfenylethyl)amido (SEA)-mediated ligation, SPPS

\section{Introduction}

Aspartimide formation is a well-known side-reaction, which often complicates the solid phase peptide synthesis (SPPS(1)). This side-reaction is due to the carboxylic acid group of the aspartic acid side-chain, which can react with the $\alpha$-nitrogen of the next residue to form a succinimide moiety called aspartimide. The aspartimide can eventually be opened by nucleophiles, typically water or hydroxide ion, to produce a peptide having a natural backbone or an isopeptidic structure depending on which aspartimide carbonyl is attacked by the nucleophile. Note that the opening of an aspartimide yields usually the isopeptide are the major product. Note also that aspartimides are prone to epimerization. Therefore, aspartimide formation can ultimately result in the formation of several byproducts. Several tools are now available for minimizing this side reaction during SPPS such as optimized Fmoc deprotection cocktails, side-chain protecting groups for aspartic acid or backbone protecting groups for the residue following Asp.(2)

Aspartimide byproduct formation can also spontaneously occur in aqueous solution at neutral $\mathrm{pH}$ and as such is one of the mechanisms that lead to the degradation of proteins in vivo with aging.(3) The 
occurrence of this side-reaction in proteins,(3) peptide therapeutics(4) and model peptides(5-7) featuring Asn or Asp residues has been the subject of numerous studies. The occurrence of Asp/AsnGly dipeptides in proteins, which are particularly prone to aspartimide formation, is on average 2.7 units per protein (1.2 for Asp-Gly, 1.5 for Asn-Gly, data extracted from UniRef50(8)). Therefore, such aspartimide-prone sites are frequent and can considerably complicate the synthesis of most proteins (see Note 1), regardless of the type of ligation used.(9)

The chemical synthesis of SUMO-2 and SUMO-3 proteins has been described in a few works using either ketoacid-hydroxylamine ligation(10) or optimized SPPS protocols.(11) In each case, the SPPS of the peptide segments was complicated by aspartimide byproduct formation due to the presence of two Asp-Gly units in SUMO-2 and 3 domains (Figure 1). Aspartimide byproduct formation during SPPS could be suppressed by using Fmoc-Asp(OtBu)-(Dmb)Gly-OH dipeptide unit for introducing the Asp and Gly residues.

During our investigations on the chemical synthesis of SUMO-2 and 3 proteins by SEA-mediated ligation,(12) we also found that the use of Fmoc-Asp(OtBu)-(Dmb)Gly-OH dipeptide unit during the SPPS of the peptide segments was mandatory for suppressing aspartimide byproduct formation. Performing the ligation of the peptide segments under classical experimental conditions $(\mathrm{pH} 5.5,4-$ mercaptophenylacetic acid (MPAA),(13) $37^{\circ} \mathrm{C}$ ) resulted in the concomitant formation of the target SUMO protein and of a -18 uma contaminant ( 20\% by MALDI-TOF), which could not be separated by HPLC. Interestingly, lowering the temperature of the ligation mixture to $25{ }^{\circ} \mathrm{C}$ enabled greatly minimizing the side-reaction and the isolation of the target proteins in good yield and purity. $(\mathbf{1 4 , 1 5 )}$

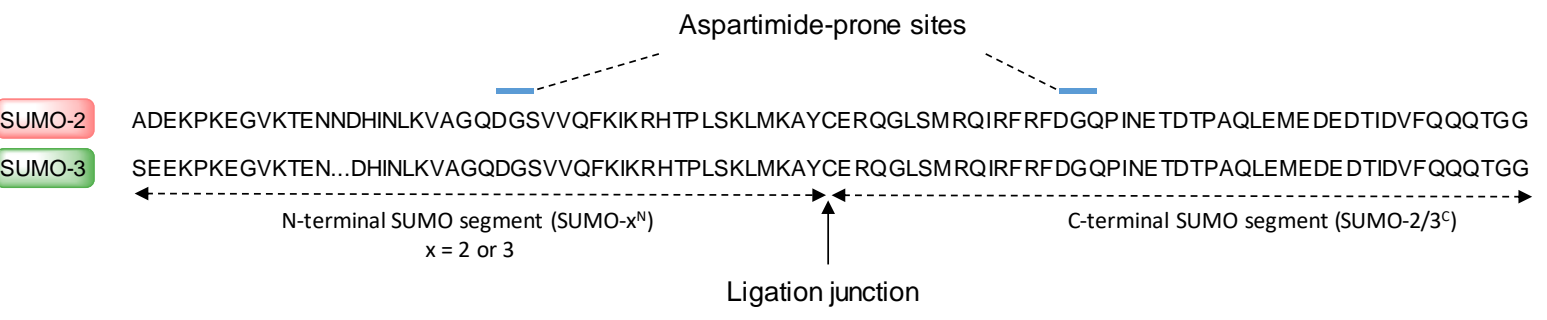

Figure 1. Sequences of SUMO-2 and 3 proteins showing the presence of an Asp-Gly dipeptide unit on both sides of the ligation site.

This protocol details the chemical synthesis of SUMO-2 and 3 proteins by SEA-mediated ligation at 25 ${ }^{\circ} \mathrm{C}$ in the presence of MPAA. The presence in SUMO proteins of a Cys residue in central position enabled 
their assembly by ligating two peptide segments of about 45 amino acids (Figure 1). The $\mathrm{N}$-terminal peptide segments, i.e., SUMO- $x^{N}(x=2$ or 3 ) were produced by 9-fluorenylmethyloxycarbonyl (Fmoc) SPPS using bis(2-sulfanylethyl)amino (SEA) ChemMatrix ${ }^{\circledR}$ resin (Fig. 2A).(16,17) The C-terminal peptide segment SUMO- $2 / 3^{C}$ is the same for both proteins. It was produced by Fmoc SPPS starting from 4hydroxymethylphenoxyacetyl (HMPA) ChemMatrix ${ }^{\circledR}$ resin (Fig. 2B).

A)

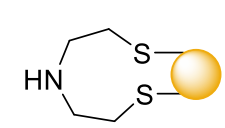

SEA-ChemMatrix resin
1. Peptide elongation

(automated Fmoc-SPPS

Fmoc-Aa $a_{\mathrm{i}}-\mathrm{OH}, \mathrm{HBTU}$, DIEA)

2. Deprotection and cleavage

(TFA + scavenger cocktail)

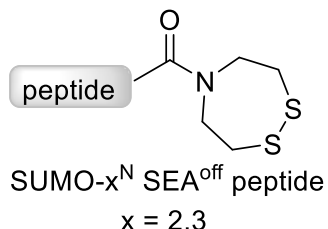

$x=2,3$

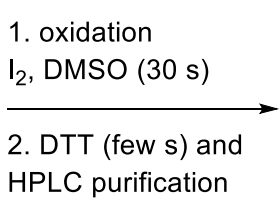

B)

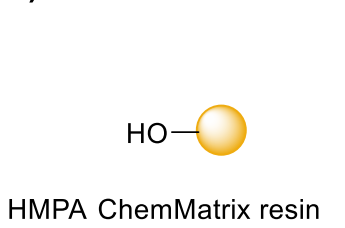

\section{Peptide elongation}

(automated Fmoc-SPPS

Fmoc-Aa $\left.\mathrm{i}_{\mathrm{i}} \mathrm{OH}, \mathrm{HBTU}, \mathrm{DIEA}\right)$

2. Deprotection and cleavage (TFA + scavenger cocktail)

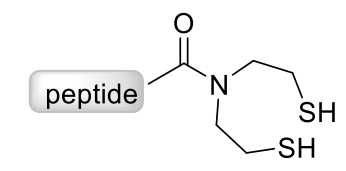

Crude SUMO- $\mathrm{x}^{\mathrm{N}}$ SEA ${ }^{\text {on }}$ peptide

$$
x=2,3
$$

C)
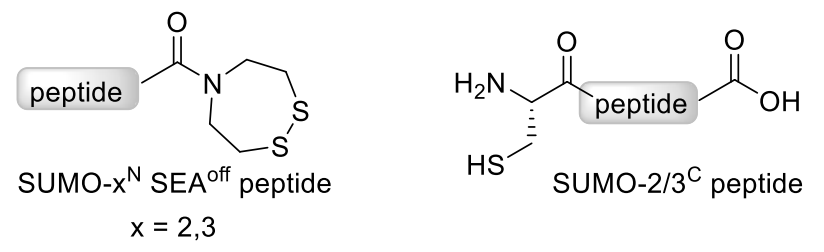

$x=2,3$
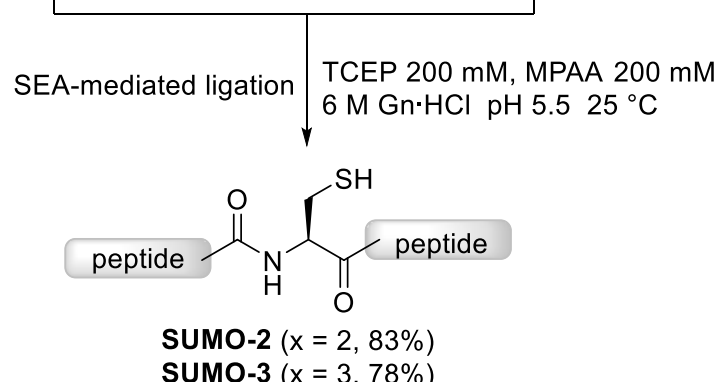

Figure 2. Synthesis of SUMO-2 and 3 proteins by SEA-mediated ligation. A) SPPS of the N-terminal segments using SEA-ChemMatrix ${ }^{\circledR}$ resin. B) SPPS of the C-terminal segment using 4hydroxymethylphenoxyacetyl (HMPA) ChemMatrix ${ }^{\circledR}$ resin. C) Assembly of SUMO-2 and 3 proteins by SEA-mediated ligation at $25^{\circ} \mathrm{C}$. 


\section{Materials \& Instruments}

All organic solvents and chemicals used in this protocol should be handled inside a chemical fume hood with appropriate personal protective equipment (lab coat, gloves and protective glasses). TFA is strongly corrosive and toxic.

\subsection{General}

1. Synthesis of bis(2-sulfanylethyl)aminotrityl ChemMatrix (SEA ChemMatrix) resin was carried out as described elsewhere.(16,17)

2. HMPA ChemMatrix resin (IRIS Biotech, Lot 08K11-20-03-043).

3. Dichloromethane RPE ACS stabilised with amylene (DCM; Carlo Erba, Cat. No. 463314).

4. N,N-Dimethylformamide for peptide synthesis (DMF; Carlo Erba, Cat. No. P0343521).

5. 1-Methyl-2-pyrrolidinone (NMP; Carlo Erba, Cat. No. P0873521)

6. Resins were conditioned in DCM $(3 \times 2 \mathrm{~min}, 3 \mathrm{~mL})$ and then in DMF $(3 \times 2 \mathrm{~min}, 3 \mathrm{~mL})$ in a manual SPPS glass reactor prior to their use.

7. N $\alpha$-Fmoc protected amino acids were obtained from Iris Biotech $\mathrm{GmbH}$ : Fmoc-Ala-OH, Fmoc$\operatorname{Arg}(\mathrm{Pbf})-\mathrm{OH}, \mathrm{Fmoc}-\mathrm{Asn}(\mathrm{Trt})-\mathrm{OH}, \mathrm{Fmoc}-\mathrm{Asp}(\mathrm{OtBu})-\mathrm{OH}, \mathrm{Fmoc}-\mathrm{Asp}(\mathrm{O} t \mathrm{Bu})[\mathrm{Dmb}-\mathrm{Gly}]-\mathrm{OH}, \mathrm{Fmoc}-$ $\mathrm{GIn}(\mathrm{Trt})-\mathrm{OH}, \mathrm{Fmoc}-\mathrm{Glu}(\mathrm{OtBu})-\mathrm{OH}, \mathrm{Fmoc}-\mathrm{Gly}-\mathrm{OH}, \mathrm{Fmoc}-\mathrm{His}(\mathrm{Trt})-\mathrm{OH}$, Fmoc-lle-OH, Fmoc-Leu$\mathrm{OH}$, Fmoc-Lys(Boc)-OH, Fmoc-Met-OH, Fmoc-Phe-OH, Fmoc-Pro-OH, Fmoc-Ser(tBu)-OH, Fmoc-Thr(tBu)-OH, Fmoc-Tyr(tBu)-OH, Fmoc-Val-OH, Fmoc-Cys(StBu)-OH or Fmoc-Cys(Trt)$\mathrm{OH}$.

8. $\quad N$-[(dimethylamino)-1H-1,2,3-triazolo-[4,5-b]pyridin-1-ylmethylene]- $N$ methylmethanaminium hexafluorophosphate $\mathrm{N}$-oxide (HATU; Novabiochem, Cat. No. 01-620041).

9. $N$-[(1H-benzotriazol-1-yl)(dimethylamino)methylene]- $N$-methylmethanaminium hexafluorophosphate N-oxide (HBTU; IRIS Biotech, Cat. No. RL-1030).

10. N,N-Diisopropylethylamine (DIEA; SDS, Cat. No. 0403516).

11. Acetaldehyde (Aldrich, Cat. No. 110078), 2 vol-\% in DMF.

12. $p$-Chloranil (Acros, Cat. No. 213561000), 2 wt-\% in DMF.

13. 2,4,6-Trinitrobenzenesulfonic acid (TNBS, TIC Europe N.V, Cat. No. 2508-19-2)

14. $N, N^{\prime}$-diisopropylcarbodiimide (DIC, Acros, Cat. No. 446181000)

15. 4-(dimethylamino)pyridine (DMAP, Aldrich chemie, Cat. No. 10 770-0)

16. Acetic anhydride $\left(\mathrm{Ac}_{2} \mathrm{O}\right)$ was purchased from Biosolve and Fisher-Chemical. 
17. UV spectrophotometer

18. Precision quartz cell (length10 mm, quartz suprasil, Hellma, Cat. No. 117104-05)

19. Diethyl ether RPE stabilised with 2,6-bis(1,1-dimethylethyl)-4-methylphenol (Carlo Erba, Cat. No. 447523)

20. Piperidine for peptide synthesis (Biosolv, Cat. No. 16183302).

21. Thioanisole (Fluka, Cat. No. 88470).

22. Thiophenol (Alfa Aesar, Cat. No.10201873)

23. Trifluoroacetic acid (TFA; Biosolv, Cat. No. 20233301).

24. Triisopropylsilane (TIS; Aldrich, Cat. No. 23378-1).

25. 1,2-Ethanedithiol, 99\% (EDT, Aldrich, Cat. No. E360-0).

26. $n$-Heptane (Biosolv, Cat. No. 0805202).

27. Water was purified with a Milli-Q Ultra Pure Water Purification System.

28. Dithiothreitol (DTT; Acros Organics, Cat. No. 16568-0050).

29. Iodine (Acros Organics, Cat. No. 38705100).

30. 0.1\% TFA in water, Optima LC/MS (Fisher Chemical, Cat. No. LS119-212).

31. $0.1 \%$ TFA in acetonitrile, Optima LC/MS (Fisher Chemical, Cat. No. LS119-212).

32. Sodium dihydrogen phosphate dihydrate $\left(\mathrm{NaH}_{2} \mathrm{PO}_{4} \cdot 2 \mathrm{H}_{2} \mathrm{O}\right.$, Prolabo, Cat. No. 28015294).

33. Disodium hydrogen phosphate dihydrate $\left(\mathrm{Na}_{2} \mathrm{HPO}_{4} \cdot 2 \mathrm{H}_{2} \mathrm{O}\right.$, Prolabo, Cat. No. 28015294).

34. Guanidine hydrochloride (Gn·HCl; Aldrich, Cat. No. G4505).

35. Glacial acetic acid (AcOH) (Carbo Erba, Cat. No. 401422).

36. Nitrogen gas $\left(\mathrm{O}_{2}<3 \mathrm{ppm}\right.$, Air Liquide).

37. Argon (Alphagaz Airliquide).

38. Hydrochloric acid ( $\mathrm{HCl}$; Sigma Aldrich, Cat. No. 32-0331-500 mL).

39. Sodium hydroxide ( $\mathrm{NaOH}$; VWR, Cat. No. 28240292).

40. Tris(2-carboxyethyl)phosphine hydrochloride (TCEP.HCl; Aldrich, Cat. No. C4706-10G).

41. 4-mercaptophenylacetic acid (MPAA; Alfa Aesar, Cat. No. H27658).

42. Conical tubes $(15 \mathrm{~mL}, 50 \mathrm{~mL})$.

43. Thermomixer comfort (Eppendorf) equipped with a block heater $\left(25^{\circ} \mathrm{C}\right)$

44. A set of adjustable pipettes $(0.5-10,2-20,10-50,10-100,100-1,000 \mu \mathrm{L}$, Eppendorf)

45. Pipette tips, $0.5-10,2-20,20-200,100-1,000 \mu L(V W R)$.

46. $\mathrm{pH}$ meter

47. Vortex shaker.

48. Microfuge tubes (1.5 mL safe-lock tubes; Eppendorf).

\subsection{HPLC analysis \& purification}


1. TFA $10 \%$ (vol/vol) in water. Add carefully $10 \mathrm{~mL}$ of TFA to $90 \mathrm{~mL}$ of deionized water.

2. Eluent $A$ for semi-preparative HPLC. TFA $0.1 \%$ (vol/vol) in deionized water. Add carefully $10 \mathrm{~mL}$ of $10 \%$ aqueous TFA (vol/vol) to $990 \mathrm{~mL}$ of deionized water.

3. Eluent B for semi-preparative HPLC. HPLC $80 \%$ (vol/vol) containing $0.1 \%$ (vol/vol) TFA. Add 10 $\mathrm{mL}$ of $10 \%$ aqueous TFA (vol/vol) to $990 \mathrm{~mL}$ of $\mathrm{ACN} 80 \%$ (vol/vol) in deionized water.

4. Analytical UPLC-MS system: Dionex UltiMate 3000/ LCQ Fleet Ion Trap, Dionex DA detector (215-280 nm), Corona Veo charged aerosol detector, ES+, m/z range 300-2000, capillary voltage $2.8 \mathrm{kV}$, cone voltage $10 \mathrm{~V}$, tube lens $75 \mathrm{~V}$, capillary voltage temperature $350^{\circ} \mathrm{C}$.

5. Analytical UPLC-MS column: Acquity UPLC peptide BEH300 C18 reverse-phase column $(2.1 \times$ $100 \mathrm{~mm}$; pore size $300 \AA \AA$; particle size: $1.7 \mu \mathrm{m}$ ).

6. Semi-preparative HPLC system (Waters 600 controller, UV 2487 Detector, 215 nm, TL 105 HPLC column heater).

7. Semi-preparative HPLC column: Waters XBridge BEH 300 C18 reverse-phase column $(10 \times 250$ mm; pore size $300 \AA ̊$; particle size: $5 \mu \mathrm{m}$ ).

\subsection{Lyophilization}

1. Lyophilizer (Christ Gamma 2-20) equipped with a manifold.

2. Lyophilizer flasks (VWR, $300 \mathrm{~mL}$, Cat. No. 88516; $600 \mathrm{~mL}$, Cat. No. 88517).

3. Liquid nitrogen

4. Dewar

\subsection{MALDI-TOF analysis}

1. MALDI-TOF mass spectrometer (Autoflex Speed, Bruker).

2. 2,5-dihydrobenzoic acid (DHB, Aldrich, Cat. No. 490799).

3. A solution of DHB $20 \mathrm{mg} / \mathrm{mL}$ in $50 \%$ aqueous acetonitrile containing $0.1 \%$ TFA.

\section{Solid phase peptide synthesis of the peptide segments}

1. Column peptide synthesizer (Multipep Intavis AG Bioanalytical instrument equipped with a 6column module)

2. Synthesis columns (Intavis, Cat. No. 35760)

3. Reaction columns (Intavis, Cat. No. 34274)

4. Manual peptide synthesis vessels

5. Fmoc amino acid solutions, Fmoc-AA-OH 0.54 M in DMF.

6. DIEA solution, DIEA 35\% in NMP (vol/vol). 
7. HBTU solution: HBTU $0.54 \mathrm{M}$ in DMF.

8. Piperidine solution $20 \%$ in DMF (vol/vol), see Note 2.

9. Capping solution, acetic anhydride 10\%/DIEA 5\%/DMF 85\% (vol/vol/vol), see Note 3 .

\subsection{Coupling of first amino acid to the SEA-Trt ChemMatrix® resin}

1. Weigh the amino acid Fmoc-Tyr(OtBu)-OH (459 mg, $1.00 \mathrm{mmol}, 10$ equiv) in a plastic tube.

2. Weigh $377 \mathrm{mg}$ ( $0.95 \mathrm{mmol}, 9.5$ equiv) of HATU in a plastic tube, see Note 4.

3. Add $5 \mathrm{~mL}$ of DMF to the tubes and agitate with a vortex shaker to dissolve the reagents.

4. Transfer the HATU/DMF solution to the tube containing the amino acid solution with an adjustable pipette.

5. Add $348 \mu \mathrm{L}$ ( $2.00 \mathrm{mmol}, 20$ equiv) of DIEA to the tube with an adjustable pipette and agitate with a vortex shaker for $1 \mathrm{~min}$. The solution becomes yellow upon addition of the base.

6. Transfer the activated amino acid/DMF solution to the reaction column.

7. Agitate with a laboratory flask shaker for $1 \mathrm{~h} 30 \mathrm{~min}$ and drain the column.

8. Aspirate $5-10 \mathrm{~mL}$ of $\mathrm{DMF}$, agitate for $2 \mathrm{~min}$ and then drain the column.

9. Repeat Step 8 twice.

10. Take a sample of the resin and perform the chloranil test which must be negative (colorless resin beads).

11. Acetylate remaining amino groups eventually present on the Fmoc-Tyr(OtBu)-SEA-Trt ChemMatrix resin by adding $5 \mathrm{~mL}$ of acetic anhydride/DIEA/DMF capping solution to the resin. Shake for $10 \mathrm{~min}$ and drain, see Note 5.

12. Repeat Step 11 twice.

13. Wash the resin with DMF $(3 \times 2 \mathrm{~min}, 5 \mathrm{~mL})$.

14. Wash the resin with DCM $(3 \times 2 \mathrm{~min}, 5 \mathrm{~mL})$.

15. Aspirate $5 \mathrm{~mL}$ of diethyl ether, shake for $2 \mathrm{~min}$ and then drain the column.

16. Repeat Step 15 twice.

17. Determine the loading of the Fmoc-Tyr(OtBu)-SEA Trt ChemMatrix resin by treating the resin with the $20 \%$ piperidine solution in DMF and UV quantification of the formed dibenzofulvenepiperidine adduct at $290 \mathrm{~nm}$ as described elsewhere.(16) Typical loading for Fmoc-Tyr(OtBu)SEA-Trt ChemMatrix resin: $0.22 \mathrm{mmol} / \mathrm{g}$.

\subsection{Coupling of first amino acid to the HMPA ChemMatrix ${ }^{\circledR}$ resin}

1. Weigh HMPA ChemMatrix ${ }^{\circledR}$ resin $(500 \mathrm{mg})$.

2. Weigh the amino acid Fmoc-Gly-OH $(297 \mathrm{mg}, 1.00 \mathrm{mmol})$ in a plastic tube.

3. Weight $12.2 \mathrm{mg}(0.100 \mathrm{mmol})$ of DMAP. 
4. Add $5 \mathrm{~mL}$ of DMF to the tube containing the amino acid to dissolve it.

5. Add $78.3 \mu \mathrm{L}(0.500 \mathrm{mmol})$ of DIC to the tube containing the amino acid solution with an adjustable pipette.

6. Transfer the activated amino acid/DIC solution to the reaction column.

7. Add DMAP in one portion to the reaction column.

8. Agitate with a laboratory flask shaker for $2 \mathrm{~h}$ at room temperature.

9. Aspirate 5-10 $\mathrm{mL}$ of DMF, agitate for $2 \mathrm{~min}$ and drain the column.

10. Repeat Step 9 twice.

11. Wash the resin with DMF $(3 \times 2 \mathrm{~min}, 5 \mathrm{~mL})$.

12. Wash the resin with DCM $(3 \times 2 \mathrm{~min}, 5 \mathrm{~mL})$.

13. Add $5 \mathrm{~mL}$ of diethyl ether, shake for $2 \mathrm{~min}$ and drain the column.

14. Repeat Step 13 twice

15. Determine the loading of the Fmoc-Gly-HMPA ChemMatrix ${ }^{\circledR}$ resin after treating an aliquot with $20 \%$ piperidine solution in DMF and reading the absorbance of the supernatant at 290 $\mathrm{nm}$. Typical loading for Fmoc-Gly-HMPA ChemMatrix ${ }^{\circledR}$ resin: $0.58 \mathrm{mmol} / \mathrm{g}$.

\subsection{First elongation using the automated peptide synthesizer}

Elongate Fmoc-Tyr(OtBu)-SEA-Trt ChemMatrix resin and Fmoc-Gly-HMPA ChemMatrix ${ }^{\circledR}$ resin using the automated peptide synthesizer, see Note 6.

Elongated sequence using Fmoc-Tyr(OtBu)-SEA-Trt ChemMatrix resin (SUMO-2 ${ }^{\mathrm{N}}$ and SUMO$3^{\mathrm{N}}$ ): SVVQFKIKRHTPLSKLMKA

Elongated sequence using Fmoc-Gly-HMPA ChemMatrix ${ }^{\circledR}$ resin (SUMO-2/3C): QPINETDTPAQLEMEDEDTIDVFQQQTG

\subsection{Manual coupling of Fmoc-Asp(OtBu)[Dmb]Gly-OH}

1. Weigh Fmoc-Asp(OtBu)[Dmb]Gly-OH $(186 \mathrm{mg}, 0.300 \mathrm{mmol}, 3$ equiv) in a plastic tube.

2. Weigh $108 \mathrm{mg}$ of HATU (108 mg, $0.284 \mathrm{mmol}, 2.85$ equiv) in the plastic tube.

3. Add $3 \mathrm{~mL}$ of DMF to the tube containing HATU and agitate with a vortex shaker to dissolve the reagent.

4. Transfer the HATU/DMF solution to the tube containing the amino acid solution with an adjustable pipette.

5. Add $104 \mu \mathrm{L}$ of DIEA ( $0.600 \mathrm{mmol}, 6$ equiv) to the tube with an adjustable pipette and agitate with a vortex shaker for $1 \mathrm{~min}$. The solution becomes yellow upon addition of the base.

6. Transfer the activated amino acid/DMF solution to the reaction column. 
7. Agitate with a laboratory flask shaker for $2 \mathrm{~h}$ and then drain the column.

8. Aspirate $5-10 \mathrm{~mL}$ of $\mathrm{DMF}$, agitate for $2 \mathrm{~min}$ and drain the column.

9. Repeat Step 8 twice

10. Take a sample of the resin and perform a TNBS test that must be negative (colorless resin beads), see Note 7 .

11. Optional: analysis of the elongated peptide by MALDI-TOF after cleavage and deprotection, see Steps 12-14.

12. Treat an aliquot of the peptidyl resin with $200 \mu \mathrm{L}$ of $20 \%$ piperidine to remove the $\mathrm{N}$-terminal Fmoc group.

13. Remove the piperidine solution with $1 \mathrm{~mL}$ of diethyl ether using a Pasteur pipette and dry the resin under a gentle flow of argon.

14. Perform the TFA cleavage for $1 \mathrm{~h}$ by adding $70 \mu \mathrm{L}$ of the cleavage mixture to the resin aliquot: TFA/triisopropylsilane (TIS)//thioanisole/ $\mathrm{H}_{2} \mathrm{O} /$ thiophenol: $87.5 / 5 / 2.5 / 2.5 / 2.5$ by vol $(1 \mathrm{~mL}$ ) for SEA ChemMatrix ${ }^{\circledR}$ resin, or TFA/TIS/ $\mathrm{H}_{2} \mathrm{O} /$ ethanedithiol (EDT): $90 / 5 / 2.5 / 2.5$ by vol $(1 \mathrm{~mL})$ for HMPA-ChemMatrix ${ }^{\circledR}$ resin.

Take $1 \mu \mathrm{L}$ of the cleavage mixture, dilute with water $(50 \mu \mathrm{L})$ and analyze by MALDI-TOF to confirm the successful elongation of the peptide chain including the coupling of the dipeptide unit. Elongated sequence using Fmoc-Tyr(OtBu)-SEA-Trt ChemMatrix resin (SUMO-2 ${ }^{\mathrm{N}}$ and SUMO-3 ${ }^{\mathrm{N}}$ ): DGSVVQFKIKRHTPLSKLMKAY $[\mathrm{M}+\mathrm{H}]^{+}$calc. 2663.45, found 2664.86.

Elongated sequence using Fmoc-Gly-HMPA ChemMatrix ${ }^{\circledR}$ resin (SUMO-2/3 ${ }^{C}$ ): DGQPINETDTPAQLEMEDEDTIDVFQQQTGG [M+H] ${ }^{+}$calc. 3421.48, found 3422.10. See Note 8.

15. Continue the synthesis by acetylating unreacted amino groups eventually present on the HMPA or SEA ChemMatrix ${ }^{\circledR}$ peptidyl resins by adding $5 \mathrm{~mL}$ of acetic anhydride/DIEA/DMF capping solution to the solid support. Shake for $10 \mathrm{~min}$ and drain

16. Repeat Step 15 twice

17. Add $5 \mathrm{~mL}$ of DMF to the column shake for $2 \mathrm{~min}$ and drain the column.

18. Repeat Step 17 twice

\subsection{Second elongation using automated peptide synthesizer}

Elongate the peptidyl resins using the automated peptide synthesizer.

Elongated sequence for SEA-Trt ChemMatrix resin: ADEKPKEGVKTENNDHINLKVAGQ for SUMO-2 ${ }^{\mathrm{N}}$, SEEKPKEGVKTENDHINLKVAGQ for SUMO-3 ${ }^{\mathrm{N}}$.

Elongated sequence for HMPA ChemMatrix ${ }^{\circledR}$ resin: CERQGLSMRQIRFRF for SUMO-2/3ㄷ.

\subsection{Cleavage step}


1. In a graduated cylinder add $8.75 \mathrm{~mL}$ of TFA, $0.25 \mathrm{~mL}$ of deionized water, , $0.25 \mathrm{~mL}$ of thiophenol, $0.25 \mathrm{~mL}$ of thioanisole and $0.50 \mathrm{~mL}$ of TIS for peptides SUMO- $x^{\mathrm{N}}(\mathrm{x}=2,3)$.

2. In a graduated cylinder add $9 \mathrm{~mL}$ of TFA, $0.25 \mathrm{~mL}$ of deionized water, $0.25 \mathrm{~mL}$ of EDT and 0.50 $\mathrm{mL}$ of TIS for peptide SUMO-2/3'.

3. Transfer each peptidyl resin in a different manual peptide synthesis vessel.

4. Add the TFA solution to the manual peptide synthesis vessel and agitate at room temperature for $2 \mathrm{~h}$

5. In the meantime, prepare three $300 \mathrm{~mL}$ Erlenmeyer flasks, each containing a mixture of $\mathbf{1 5 0}$ $\mathrm{mL}$ of diethyl ether and $150 \mathrm{~mL}$ of $n$-heptane. Add magnetic bars and place the Erlenmeyer flasks in an ice bath.

6. Precipitate the peptides by adding the peptide solutions dropwise to the ice-cold diethyl ether/n-heptane mixture with magnetic stirring.

7. Add $5 \mathrm{~mL}$ of TFA to each peptide reactor, shake the bead suspensions for $2 \mathrm{~min}$ and then add this solution dropwise to the Erlenmeyer flask.

8. Repeat Step 7, see Note 9.

9. Transfer the suspensions to centrifuge tubes and centrifuge at $1,900 \times \mathrm{g}$ for $10 \mathrm{~min}$, then pour carefully the supernatant into an Erlenmeyer flask.

10. Add $40 \mathrm{~mL}$ of cold diethyl ether $50 \% / n$-heptane $50 \%$ ( $\mathrm{vol} / \mathrm{vol}$ ) to the peptide, triturate the peptide pellet and centrifuge again at 1,900 $\times \mathrm{g}$ for $10 \mathrm{~min}$, then pour carefully the supernatant into the Erlenmeyer flask.

11. Carefully flush the tubes with nitrogen to evaporate the residual solvent.

12. Dissolve the crude peptides in TFA $0.1 \%$ (vol/vol) in deionized water and place the peptide solutions immediately at $-20^{\circ} \mathrm{C}$ overnight, see Note 10 .

13. Lyophilize for 2 days.

14. Analyze the crude peptide by UPLC-MS and MALDI-TOF mass spectrometry

\subsection{Oxidation SEA ${ }^{\text {on }}$ peptides. Purification of SUMO- $x^{N}$ SEA ${ }^{\text {off }}$ peptides $(x=2,3)$}

1. Prepare the semi-preparative HPLC system, which should be ready before starting the oxidation of the peptides.

2. Rapidly weigh $100-150 \mathrm{mg}$ of iodine in a $5 \mathrm{~mL}$ volumetric flask. Immediately add the DMSO up to $5 \mathrm{~mL}$. Calculate the concentration of iodine, see Note 11.

3. Prepare a solution of DTT $10 \mathrm{mg} / \mathrm{mL}$ in deionised water.

4. Dissolve the crude peptide in phosphate buffer/ $\mathrm{Gn} \cdot \mathrm{HCl} 6 \mathrm{M}$ at room temperature (peptide concentration $0.25 \mathrm{mM}$ ), see Note 12 . 
5. Add 2 equivalents of iodine in DMSO to the peptide solution. The solution becomes yellow indicating that an excess of iodine has been added to the peptide solution.

6. Vortex the solution for $30 \mathrm{~s}$, see Note 13.

7. Then immediately add a few drops of the DTT solution with a Pasteur pipette until the yellow color disappears, indicating that the excess of iodine has been decomposed.

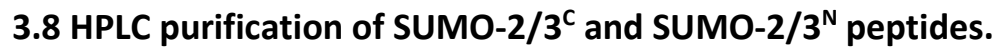

1. Purify immediately by semi preparative HPLC.

2. Gradient used for the HPLC purification of peptide SUMO-2 ${ }^{\mathrm{N}}$ : eluent $A$ water containing $0.1 \%$ of TFA, eluent $\mathrm{B} \mathrm{CH} \mathrm{CH}_{3} \mathrm{CN} /$ water : $4 / 1$ by vol containing $0.1 \%$ of TFA, gradient: $0-25 \% \mathrm{~B}$ in 5 min, then $25-35 \% \mathrm{~B}$ in $40 \mathrm{~min}$, flow rate $6 \mathrm{~mL} / \mathrm{min}, 50^{\circ} \mathrm{C}$, UV detection at $215 \mathrm{~nm}$.

3. Yield for peptide SUMO-2 ${ }^{\mathrm{N}}$ : $34.4 \mathrm{mg}$ of crude product furnished $(11.2 \mathrm{mg})$ of SUMO-2 ${ }^{\mathrm{N}}$, Calculated for M (average mass) 5281.17, observed 5281.13 by LC-MS after deconvolution.

4. Gradient used for the HPLC purification of peptide SUMO-3 ${ }^{\mathrm{N}}$ : eluent $A$ water containing $0.1 \%$ of TFA, eluent $\mathrm{B} \mathrm{CH}_{3} \mathrm{CN} /$ water : $4 / 1$ by vol containing $0.1 \%$ of TFA, gradient: $0-25 \%$ B in 5 min, then $25-35 \%$ B in $40 \mathrm{~min}$, flow rate $6 \mathrm{~mL} / \mathrm{min}, 50^{\circ} \mathrm{C}$, UV detection at $215 \mathrm{~nm}$.

5. Yield for peptide SUMO-3 ${ }^{\mathrm{N}}: 30.8 \mathrm{mg}$ of crude product furnished $(11.2 \mathrm{mg})$ of SUMO-3 $\mathbf{S}^{\mathrm{N}}$, Calculated for M (average mass) 5197.09, observed 5197.17 by LC-MS after deconvolution.

6. Gradient used for the HPLC purification of peptide SUMO-2/3 $\mathbf{3}^{\mathrm{C}}$ : eluent $\mathrm{A}$ water containing $0.1 \%$ of TFA, eluent $\mathrm{B} \mathrm{CH}{ }_{3} \mathrm{CN} /$ water : $4 / 1$ by vol containing $0.1 \%$ of TFA, gradient: $0-20 \%$ B in 5 min, then $20-40 \%$ B in $40 \mathrm{~min}$, flow rate $6 \mathrm{~mL} / \mathrm{min}, 50^{\circ} \mathrm{C}$, UV detection at $215 \mathrm{~nm}$

7. Yield for peptide SUMO-2/3': $31.3 \mathrm{mg}$ of crude product furnished (10.6 mg) of SUMO-2/3c, Calculated for M (average mass) 5331.82, observed 5331.95 by LC-MS after deconvolution.

8. Analyze the collected fractions by analytical UPLC-MS and pool the pure fractions in a $50 \mathrm{~mL}$ plastic tube.

9. Place the tubes in liquid nitrogen to freeze the peptide solutions and lyophilize for two or three

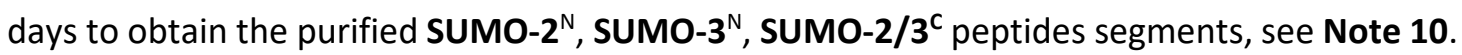

\section{Synthesis of SUMO-2 and 3}

1. Weigh $5.38 \mathrm{mg}$ ( 1 equiv, $0.825 \mu \mathrm{mol}, 4 \mathrm{mM}$ ) of SUMO- $\mathrm{x}^{\mathrm{N}} \mathrm{SEA}^{\text {off }}$ peptide $(\mathrm{x}=2$ or 3 ) in a $1.5-\mathrm{mL}$ microfuge tube.

2. Weigh $4.94 \mathrm{mg}$ ( 1 equiv, $0.825 \mu \mathrm{mol}, 4 \mathrm{mM}$ ) of cysteinyl peptide SUMO-2/3 ${ }^{\mathrm{C}}$ in a $1.5-\mathrm{mL}$ microfuge tube.

3. Weigh $13.42 \mathrm{mg}(79.77 \mu \mathrm{mol}, 200 \mathrm{mM}$ final concentration) of MPAA in a 1.5-mL microfuge tube.

4. Weigh $31.6 \mathrm{mg}(110 \mu \mathrm{mol}, 200 \mathrm{mM}$ final concentration) of TCEP in a $1.5-\mathrm{mL}$ microfuge tube. 
5. Prepare $2 \mathrm{~mL}$ of $0.1 \mathrm{M}$ sodium phosphate buffer $(\mathrm{pH} 7.2) / 6 \mathrm{M} \mathrm{Gn} \cdot \mathrm{HCl}$.

6. Transfer $1 \mathrm{~mL}$ of $\mathrm{AcOH}$ glacial, $1 \mathrm{~mL}$ of $\mathrm{HCl} 1 \mathrm{~N}$ and $1 \mathrm{~mL}$ of $\mathrm{NaOH} 6 \mathrm{~N}$ in three different $1.5-\mathrm{mL}$ microfuge tubes.

7. Cap all the tubes and transfer them to the glove box under nitrogen atmosphere.

8. Add $0.551 \mathrm{~mL}$ of the sodium phosphate buffer from Step 5 to the microfuge tube containing TCEP (see Step 4). Vortex until dissolution of the TCEP and transfer $0.399 \mathrm{~mL}$ of this solution to the microfuge tube containing MPAA (see Step 3). Add NaOH $6 \mathrm{~N}(30 \mu \mathrm{L}$ ) with the micropipette and vortex until dissolution of the MPAA. The final reagent concentration is $181 \mathrm{mM}$ for MPAA and $181 \mathrm{mM}$ for TCEP.

9. Measure the $\mathrm{pH}$ of the solution prepared in Step 8 and adjusts to $\mathrm{pH} 5.5$ by adding $\mathrm{NaOH} 6 \mathrm{~N}$ or $\mathrm{HCl} 1 \mathrm{~N}$ with the micropipette $(2-20 \mu \mathrm{L})$.

10. Add $0.205 \mathrm{~mL}$ of the solution prepared in Step 8 to the microfuge tube containing the SUMO$x^{N}$ SEA ${ }^{\text {off }}$ peptide (see Step 1). Vortex to dissolve the peptide and then add this solution to the microfuge tube containing the cysteinyl peptide SUMO-2 $/ 3^{\mathrm{C}}$ (see Step 2). Vortex to dissolve the peptide.

11. Place the reaction tube from Step 10 in a thermomixer kept at $25^{\circ} \mathrm{C}$ with agitation.

12. To monitor the ligation reaction (just after preparing the reaction mixture at Step 10 and every 6-7 hour until $33 \mathrm{~h}$ of reaction, transfer $1.5 \mu \mathrm{L}$ of the reaction mixture to a microfuge tube and quench the reaction by acidifying the sample with $100 \mu \mathrm{L}$ of $10 \%$ aqueous $\mathrm{AcOH}$ (vol/vol). Vortex and remove the sample from the glove box.

13. Remove MPAA present in the reaction mixture by extracting the aqueous phase with $1 \mathrm{~mL}$ of diethyl ether. Remove the diethyl ether phase with a Pasteur pipette.

14. Repeat Step 13 twice.

15. Inject $10 \mu \mathrm{L}$ of the sample isolated in Step 14 into the analytical UPLC-MS system to confirm that the starting peptide segments have been consumed to produce the ligation product SUMO-2 or 3.

16. After $33 \mathrm{~h}$, remove the reaction tube from the glove box.

17. Transfer the contents of the reaction tube into a $5-\mathrm{mL}$ microfuge tube.

18. Add $0.500 \mathrm{~mL}$ of phosphate buffer / $6 \mathrm{M} \mathrm{Gn} \cdot \mathrm{HCl}$ to the reaction mixture and $70.5 \mu \mathrm{L}$ of glacial acetic acid to a final concentration of 5-10 \% ( $\mathrm{vol} / \mathrm{vol})$ with a micropipette to acidify the solution down to a $\mathrm{pH}$ of 2-3 (pH paper).

19. Extract the MPAA from the aqueous phase with $2 \mathrm{~mL}$ of diethyl ether as done in Step 13. Remove the diethyl ether phase with a Pasteur pipette.

20. Repeat Step 19 twice.

21. Remove the dissolved diethyl ether by flushing the tube with nitrogen ( $2 \mathrm{~min})$ 
22. Purify the target SUMO-2 or 3 proteins using a Waters XBridge BEH300 C18 reverse-phase column (10 $\times 250 \mathrm{~mm}$; pore size $300 \AA \AA$; particle size : $5 \mu \mathrm{m})$ and a semi-preparative HPLC system; Gradient : $0 \%$ eluent B in eluent A to $20 \%$ (vol/vol) eluent B in eluent A over 5 min, and then $20 \%$ (vol/vol) eluent B in eluent A to $40 \%$ (vol/vol) eluent B in eluent A over 60 min (UV detection at $215 \mathrm{~nm}$ ). Analyze the fractions using the MALDI-TOF spectrometer. Mix $1.2 \mu \mathrm{L}$ of the DHB solution with $1 \mu \mathrm{L}$ of the sample on the MALDI plate and let dry at room temperature in air.

23. Pool the pure fractions in a $50 \mathrm{~mL}$ plastic tube, freeze the solution with liquid nitrogen and lyophilize it for two or three days. The reaction yields $4.20 \mathrm{mg}$ ( $78 \%$ yield) of SUMO-2 and 4.46 mg of SUMO-3 (83\% yield).

24. Analyze the purified products by UPLC-MS. ACQUITY UPLC peptide BEH C18 $300 \AA 1.7 \mu \mathrm{m} 2.1$ $\mathrm{mm} \times 150 \mathrm{~mm}, 50^{\circ} \mathrm{C}$. Flow $0.400 \mathrm{~mL} / \mathrm{min}$, eluent $\mathrm{A} 0.1 \%$ trifluoroacetic acid in water, eluent $B$ $0.1 \%$ trifluoroacetic acid in $100 \%$ acetonitrile. Gradient from 0\% eluent B to $70 \%$ eluent B in 20 $\min$.

25. SUMO-2: Calculated for $M$ (average mass) 10477.24 , observed 10476.71 after deconvolution

26. SUMO-3: Calculated for M (average mass) 10393.66, observed 10393.84 after deconvolution.

\section{Notes}

Note 1. Aspartimide byproduct formation can occur during NCL.(18) For example, the assembly of Ras protein (166 amino acid residues) by NCL yielded a product having $18 \pm 2$ uma less than expected.(19) The mass loss occurred during the last ligation and could be due to a loss of water or ammonia. The site of dehydration or deamination was not identified. For another example, see ref (20).

Note 2. The solution can be stored or used for up to 2 weeks at room temperature.

Note 3. This solution can be used up to $24 \mathrm{~h}$ after preparation. For the automated peptide elongation step, this solution is renewed every day.

Note 4. HATU is an uronium-based coupling reagent with reacts efficiently with amines and thus can cause undesired peptide termination if present in excess. To avoid the presence of unreacted HATU during the coupling step, the amino acid is used in slight molar excess and the amino acid is activated prior to the coupling step.

Note 5. The capping step is mandatory even if the chloranil test is negative, because the sensitivity of the test for the secondary amino group of the SEA resin is lower than for $\alpha$-amino groups. 
Note 6. The synthesis of the $\sim 50$ amino acids SEA ${ }^{\text {off }}$ peptide segments SUMO- $\mathbf{x}^{\mathbf{N}}$ is performed using the SEA-Trt-ChemMatrix ${ }^{\circledR}$ resin. The synthesis program must consider the large swelling volume of the starting SEA-Trt resin and the significant mass increase of the peptidyl resin that occurs during the peptide elongation step.

Note 7. We recommend to confirm the coupling of Fmoc-Asp(OtBu)[Dmb]Gly-OH by cleaving an aliquot in TFA and analyzing the cleaved peptide by MALDI-TOF.

Note 8. MALDI-TOF analysis of the cleaved peptides might show the expected peaks and also products of higher mass (+ 150 uma) due to the incomplete removal of the Dmb group.

Note 9. We recommend that the volume of the diethyl ether/ $n$-heptane solution be at least 20 times that of the peptide solution in TFA.

Note 10. The peptide solution can be frozen quickly using liquid nitrogen. The tube must be checked before starting the lyophilization because it can crack during this step.

Note 11. lodine is available as granules. Therefore, weighting a given amount of iodine precisely is difficult to achieve.

Note 12. SUMO- $\mathbf{x}^{\mathrm{N}} \mathrm{SEA}^{\text {off }}$ peptides $(\mathbf{x}=\mathbf{2 , 3})$ have a limited solubility and the use of $\mathrm{Gn} \cdot \mathrm{HCl}$, which is a classical additive for improving the solubility of the peptide segments, was mandatory in this case. lodine oxidation can be performed in the absence of $\mathrm{Gn} \cdot \mathrm{HCl}$ and at $\mathrm{mM}$ concentrations when solubility is not an issue.

Note 13. The duration of the iodine treatment should not exceed $30 \mathrm{~s}$, otherwise iodine can react with some amino acid residues such as tyrosines. For the same reason, the amount of iodine which is added to the peptide solution must not exceed two equivalents. This oxidation procedure is not compatible with the presence of free cysteine thiols on the peptide chain.

\section{Acknowledgements}

This study was supported by the National Center for Scientific Research (CNRS), the University of Lille and the Pasteur Institute of Lille.

\section{References}


(1) Merrifield RB Solid phase peptide synthesis. I. The synthesis of a tetrapeptide. J Am Chem Soc 1963;85:2149-54.

(2) Behrendt R, White P, Offer J Advances in Fmoc solid-phase peptide synthesis. J Pept Sci 2016;22:4-27.

(3) Voorter CE, de Haard-Hoekman WA, van den Oetelaar PJ, Bloemendal H, de Jong WW Spontaneous peptide bond cleavage in aging alpha-crystallin through a succinimide intermediate. J Biol Chem 1988;263:19020-3.

(4) Joshi AB, Sawai M, Kearney WR, Kirsch LE Studies on the mechanism of aspartic acid cleavage and glutamine deamidation in the acidic degradation of glucagon. J Pharm Sci 2005;94:191227.

(5) Geiger T, Clarke S Deamidation, isomerization, and racemization at asparaginyl and aspartyl residues in peptides. Succinimide-linked reactions that contribute to protein degradation. J Biol Chem 1987;262:785-94.

(6) Stephenson RC, Clarke S Succinimide formation from aspartyl and asparaginyl peptides as a model for the spontaneous degradation of proteins. J Biol Chem 1989;264:6164-70.

(7) Tyler-Cross R, Schirch V Effects of amino acid sequence, buffers, and ionic strength on the rate and mechanism of deamidation of asparagine residues in small peptides. J Biol Chem 1991;266:22549-56.

(8) Suzek BE, Huang H, McGarvey P, Mazumder R, Wu CH UniRef: comprehensive and nonredundant UniProt reference clusters. Bioinformatics 2007;23:1282-8.

(9) Agouridas V, El Mahdi O, Diemer V, Cargoet M, Monbaliu J-CM, Melnyk O Native chemical ligation and extended methods. Mechanisms, catalysis, scope and limitations. Chem Rev 2019;12:7328-443.

(10) Wucherpfennig TG, Pattabiraman VR, Limberg FRP, Ruiz-Rodríguez J, Bode JW Traceless preparation of C-terminal $\alpha$-ketoacids for chemical protein synthesis by $\alpha$-ketoacidhydroxylamine ligation: Synthesis of SUMO2/3. Angew Chem Int Ed 2014;53:12248-52.

(11) Mulder MPC, Merkx R, Witting KF, Hameed DS, El Atmioui D, Lelieveld L, Liebelt F, Neefjes J, Berlin I, Vertegaal ACO et al. Total chemical synthesis of SUMO and SUMO-based probes for profiling the activity of SUMO-specific proteases. Angew Chem Int Ed 2018;57:8958-62.

(12) Ollivier N, Dheur J, Mhidia R, Blanpain A, Melnyk O Bis(2-sulfanylethyl)amino native peptide ligation. Org Lett 2010;12:5238-41.

(13) Johnson EC, Kent SBH Insights into the mechanism and catalysis of the native chemical ligation reaction. J Am Chem Soc 2006;128:6640-6.

(14) Bouchenna J, Sénéchal M, Drobecq H, Vicogne J, Melnyk O Total Chemical Synthesis of All SUMO-2/3 Dimer Combinations. Bioconjugate Chem 2019;30:2967-73.

(15) Bouchenna J, Sénéchal M, Drobecq D, Stankovic-Valentin N, Vicogne J, Melnyk O The Role of the Conserved SUMO-2/3 Cysteine Residue on Domain Structure Investigated Using Protein Chemical Synthesis. Bioconjugate Chem 2019;30:2684-96.

(16) Boll E, Drobecq H, Ollivier N, Blanpain A, Raibaut L, Desmet R, Vicogne J, Melnyk O One-pot chemical synthesis of small ubiquitin-like modifier (SUMO) protein-peptide conjugates using bis(2-sulfanylethyl)amido peptide latent thioester surrogates Nat Protoc 2015;10:269-92.

(17) Boll E, Drobecq H, Ollivier N, Raibaut L, Desmet R, Vicogne J, Melnyk O A novel PEG-based solid support enables the synthesis of $>50$ amino-acid peptide thioesters and the total synthesis of a functional SUMO-1 peptide conjugate. Chem Sci 2014;5:2017-22.

(18) Dawson PE, Muir TW, Clark-Lewis I, Kent SBH Synthesis of proteins by native chemical ligation. Science 1994;266:776-79.

(19) Becker CF, Hunter CL, Seidel R, Kent SBH, Goody RS, Engelhard M Total chemical synthesis of a functional interacting protein pair: the protooncogene $\mathrm{H}$-Ras and the Ras-binding domain of its effector c-Raf1. Proc Natl Acad Sci U S A 2003;100:5075-80.

(20) Cowper B, Shariff L, Chen W, Gibson SM, Di W-L, Macmillan D Expanding the scope of N $\rightarrow$ S acyl transfer in native peptide sequences. Org Biomol Chem 2015;13:7469-76. 
